\title{
DRINKING WATER AVAILABILITY AND MANAGEMENT: A CASE STUDY OF SAWAI MADHOPUR DISTRICT
}

\author{
Prem Sonwal \\ Assistant Professor, Department of Geography, \\ SCRS Government College, Sawai Madhopur (Rajasthan), India \\ Email: premsonwal@gmail.com
}

\begin{abstract}
Drinking water is an essential element for living. Article 47 of the Constitution of India makes it a top priority for the governments to provide safe and clean drinking water to every citizen of the country. In India, due to a 3-fold increase in population during 1951-2010, the per capita availability of water in the country as a whole decreased from 5,177 m3/year in 1951 to $1,588 \mathrm{m3}$ year in 2010. Supply of good quality water in sufficient quantities and safe sanitation practices in urban and rural areas are interconnected with the health and economic well-being of the people. Water used for the drinking purpose is known as potable water, which must be sparklingly clear, odourless, neither hard nor too soft and free from bacteria and impurities. In Rajasthan, 91 percent of the Domestic Water requirements of Rural / Urban Sector are being catered from Groundwater Sources and only 9 percent Water requirement is being met from surface water sources. In spite of poor quality and meager quantity, the groundwater resources in the state are the only most reliable and dependable source for sustenance of life. As a result of increasing population, urbanization, expansion of irrigated agriculture and other activities, the ground water level in Sawai Madhopur district has come under the category of 'over exploitation' category and the quality of water has also come down. This paper highlights the sources of drinking water, quality of ground water and efficient management of drinking water in Sawai Madhopur district.
\end{abstract}

Key words: Ground Water, Over Exploited, Potable Water, Water requirement, NRDWP.

\section{Introduction}

Drinking water comes from surface water and ground water. Surface water includes river, Lakes and reservoirs. Ground water is siphoned from wells that are bored into aquifers. Access to reliable, safe water reduces exposure to pollution, disease, and harmful contaminants, thereby promoting health and wellbeing. The decline in groundwater levels, contamination of water sources and increases consumption are some problems related to water resources. In such a scenario, availability of safe, clean and affordable water is a big challenge. The Sustainable Development Goals 2015-2030 include Goal 6 for clean water and sanitation for ensuring their availability and sustainable management. Objective 6.1 says that by 2030, nations including India should 'achieve universal and equitable access to safe and affordable drinking water for all'. According to global reports released by the United Nations, 2.1 billion people live without safe drinking water at home and 80 per cent of those who have to use unsafe and unprotected water sources reside in rural areas. In our country, groundwater is the major source of water and around 85 percent of the population is dependent on it. Remaining 15 per cent of the rural water supply comes from surface water sources. Ground water in most cities and around 19000 villages contains fluorides, nitrate, pesticides, etc. beyond the permissible limits. Drinking water quality stays an issue and this reflects the fact that roughly 21 per cent of communicable diseases are waterborne and 75 per cent of water-related deaths are of infants under five years.

India is among the world's most water-stressed countries. According to the National Sample Survey Office (NSSO) (2011-12), 46.1 per cent of the rural households do not have drinking water facilities within their premises. A person in rural India has to spend, on an average, 20 minutes to bring drinking water. India loses 73 million working days because of water-borne diseases. Post 2012, under restructured NRDWP, the focus shifted to improving the quality of water supplied to targeted habitations. The NRDWP (National Rural Drinking water Programme) aims at providing every person on rural India with adequate safe water for drinking, cooking and other domestic basic needs on sustainable basis. For urban settings, the 
water availability of $150-200$ Ipcd is considered adequate to meet all domestic purposes. In rural India, a norm of 40 lpcd is a set target. The quality of water supplied is also a major issue. Rajasthan has been a water deficit area. The rainfall is erratic and there is a large variation in the rainfall pattern in the state. Average annual rainfall of the state is $531 \mathrm{~mm}$. Rajasthan is the largest state of the country, the status of water in the state is most critical. Rajasthan with more than 10.4 percent of the country's geographical area, supporting more than 5.67 percent of the human population and 18.70 percent of the livestock has only 1.16 percent of the total surface water and 1.70 percent of ground water available in the country. The groundwater condition is quite alarming. Total Annual Ground water Recharge of the State has been assessed as $13.21 \mathrm{bcm}$ and Annual Extractable Ground Water Resource as $11.99 \mathrm{bcm}$. The Annual Ground Water extractionis $16.77 \mathrm{bcm}$ and the Stage of ground water extraction in the state is 140 percent. Out of the 295 assessed blocks, 185 blocks have been categorized as 'Over Exploited', 33 as 'Critical', 29 as 'Semi-Critical',45 blocks as 'Safe' and 3 as 'Saline'( March, 2017).

\section{Study Area}

Sawai Madhopur district is administratively divided into six blocks Bamanwas, Bonli, Sawai Madhopur, Khandar, Gangapur City and Chauth ka Barwada. According to the 2011 census, the population of district under the urban area Sawai Madhopur is 1.21 lakh and Gangapur City is 1.19 lakh and the population of 758 habitable villages of 6 Panchayat Samities/Blocks of the rural area is 1069084. Total population of the district is 1335551 (Census 2011). Physiographically the area is characterized by partly planes and partly hilly terrain with Vindhyan plateau in the South and Southeast and occasional sand dunes towards South of village Wazirpur. The most of the rainfall is received (93.5 percent) during the monsoon months. Average annual rainfall of the district is $664 \mathrm{~mm}$. The climate of the District is semiarid to sub humid type and is subject to extremes of cold and hot at different places. The minimum and maximum temperatures recorded in Sawai Madhopur District are below $10^{\circ} \mathrm{C}$ in the month of January and above $40^{\circ} \mathrm{C}$ in the month of May respectively. The Banas, Moral, Jivad and Chambal are the main rivers in the district. The Banas is the largest among them. The overall stage of ground water development of the district is 134.55 percent (March, 2017) and the district as a whole is categorised as 'Over Exploited'.

\section{RESULT AND DISCUSSION}

\section{Drinking Water Availability in Sawai Madhopur}

The main sources of drinking water in the urban and rural areas of Sawai Madhopur district are the tubed well, open well, single phase and hand pumps. The highest number of hand pumps is in the urban area Sawai Madhopur and Gangapur. The highest hand pump in rural areas is 452 in Bonli block. The maximum number of Tube Well in the entire district is 106, which is in Sawai Madhopur city.

Table 01: Drinking Water Sources in Rural/Urban Areas of Sawai Madhopur District

\begin{tabular}{|l|l|c|c|c|c|c|c|c|c|}
\hline$\#$ & \multirow{2}{*}{ Block/City } & \multicolumn{9}{|c|}{ Total Drinking Water Sources } & \multicolumn{3}{l|}{ Working Drinking Water Sources } \\
\cline { 3 - 11 } & & TW & OW & SP & HP & TW & O/W & SP & HP \\
\hline 1. & UWSS Sawai Madhopur & 106 & 4 & 150 & 464 & 106 & 4 & 150 & 367 \\
\hline 2. & UWSS Gangapur & 48 & 2 & 45 & 288 & 48 & 2 & 45 & 260 \\
\hline 3. & Sawai Madhopur & 60 & 0 & 587 & 1150 & 45 & 0 & 540 & 616 \\
\hline 4. & Khandar & 67 & 1 & 437 & 1064 & 63 & 1 & 437 & 657 \\
\hline 5. & Bonli & 73 & 10 & 60 & 2931 & 40 & 9 & 54 & 2646 \\
\hline 6. & Chauth Ka Barwada & 60 & 8 & 300 & 1101 & 56 & 8 & 270 & 502 \\
\hline 7. & Gangapur & 83 & 13 & 155 & 2017 & 83 & 13 & 143 & 1481 \\
\hline 8. & Bamanwas & 76 & 2 & 80 & 1853 & 76 & 2 & 78 & 1730 \\
\hline & Total & 573 & 40 & 1814 & 10868 & 517 & 39 & 1717 & 8259 \\
\hline
\end{tabular}

Source: PHED, Sawai Madhopur

TW-Tube Well O/W -Open well SP-Single Phase HP-hand pump

Groundwater availability in Sawai Madhopur is highly variable, depending on hydrological conditions. The limited ground water resources in Sawai Madhopur are increasingly being exploited for irrigation and domestic uses. The District is heavily dependent on groundwater for drinking water and irrigation. Total Annual Ground water Recharge of the district has been assessed as 490.04MCM and Annual Extractable Ground Water Resource as 449.82MCM. The Annual Ground Water extraction is $605.25 \mathrm{MCM}$ and the Stage of ground water extraction 
in the district is 134.55 percent (March, 2017).Being a predominantly fresh ground water area coupled with good population and availability of agriculture land, the ground water exploitation is also very high and the ground water resource assessment studies reveal that all the blocks of the district have already exhausted the dynamic ground water resource and all the blocks fall within 'Over Exploited' category on the basis of stage of development exceeding more than 100 percent. Data regarding coverage of safe drinking water in rural areas is estimated in terms of Fully Covered Habitations (i.e. More than 40 lpcd or more safe drinking water), Partially Covered Habitations (i.e. Less than $40 \mathrm{lpcd}$ ) and Quality Affected Habitations (i.e. water with chemical contaminant). District data indicate that 73.29 percent of rural habitations have been provided with 40 lpcd or more, 23.9 percent of rural habitations get less than 40 lpcd and 2.79 percent of rural habitations affected with contaminant water.

Table 02: Status of Rural Habitation with Respect to Drinking Water Supply, 2018-19

\begin{tabular}{|l|c|c|c|c|}
\hline Category & Total & $\begin{array}{l}\text { Total Population } \\
\text { (in lacks) }\end{array}$ & $\begin{array}{l}\text { Having } \\
\text { Population }\end{array}$ & $\begin{array}{l}\text { Pot Having PWS } \\
\text { Population }\end{array}$ \\
\hline Total No of Habitations & 2179 & 10.90 & 4.01 & 6.89 \\
\hline $\begin{array}{l}\text { No of Fully Covered } \\
\text { Habitations }\end{array}$ & 1597 & 6.73 & 2.65 & 2.08 \\
\hline $\begin{array}{l}\text { No of Partially Covered } \\
\text { Habitations }\end{array}$ & 521 & 3.53 & 0.91 & 2.63 \\
\hline $\begin{array}{l}\text { No of Quality Affected } \\
\text { Habitations }\end{array}$ & 61 & 0.63 & 0.45 & 0.18 \\
\hline
\end{tabular}

Source: NRDWR

PWS - Public Water System

Ipcd - litre per capita per day

\section{Groundwater Quality}

The quality of water depends on its physical and chemical properties. Physical properties include colour, odour \& turbidity which can be determined by our senses. The chemical properties depend on the nature \& quantity of various chemical constituents individually or jointly. The presence of various chemical constituents in excess quantity in water affects the human health adversely. Contaminated water and poor sanitation are linked to transmission of diseases such as Cholera, Diarrhoea, Dysentery, Hepatitis A, Hepatitis E and Typhoid. In our country Bureau of Indian Standard has prescribed standard limits for drinking purpose (IS10500: 2012). The Acceptable limit and permissible limits for major constituents and their probable effects on human body have been shown in the following table.

Table 03: Drinking Water Standard of BIS, 10500:2012

\begin{tabular}{|c|l|c|c|c|}
\hline$\#$ & Parameters & Desirable Limit & Permissible Limit & Unit \\
\hline 1 & pH & $6.5-8.5$ & - & - \\
\hline 2 & Chloride & 250 & 1000 & $\mathrm{mg} / \mathrm{l}$ \\
\hline 3 & Total alkalinity & 200 & 600 & $\mathrm{mg} / \mathrm{l}$ \\
\hline 4 & Total Dissolved solid & 500 & 2000 & $\mathrm{mg} / \mathrm{l}$ \\
\hline 5 & Total Hardness & 200 & 600 & $\mathrm{mg} / \mathrm{l}$ \\
\hline 6 & Fluoride & 1.0 & 1.5 & $\mathrm{mg} / \mathrm{l}$ \\
\hline 7 & Iron & 0.3 & No relaxation & $\mathrm{mg} / \mathrm{l}$ \\
\hline 8 & Calcium & 75 & 200 & $\mathrm{mg} / \mathrm{l}$ \\
\hline 9 & Magnesium & 30 & 100 & $\mathrm{mg} / \mathrm{l}$ \\
\hline 10 & Sulphate & 200 & 400 & $\mathrm{mg} / \mathrm{l}$ \\
\hline 11 & Nitrate & 45 & No relaxation & $\mathrm{mg} / \mathrm{l}$ \\
\hline
\end{tabular}

Source: BIS

Dissolved nitrogen in the form of Nitrate is the most common contaminant of ground water in rural areas. Higher concentration of nitrate causes mathaemoglobinaemia or "blue baby" disease in bottle fed infants. The Bureau of Indian standard prescribed desirable limit 45 $\mathrm{mg} / \mathrm{l}$ for nitrate in drinking water and no upper limit relaxation for nitrate concentration in drinking water. Fluoride is a mineral that is found naturally in all water sources, including fresh water and sea water. It is well known that small amount of fluoride (less than $1.0 \mathrm{mg} / \mathrm{l}$ ) have proven to be beneficial in reducing tooth decay. High concentration of fluoride has an adverse effect on tooth enamel and may give rise to mild dental fluorosis The Bureau of Indian standard prescribed desirable limit $1.0 \mathrm{mg} / \mathrm{l}$ and permissible limit $1.5 \mathrm{mg} / \mathrm{l}$ for fluoride in drinking water. TDS stands for total dissolved solids, and represents the total concentration of dissolved 
substances in water. It is the sum of the cation and anion present in water. Total dissolved solid is refers to carbonates, bicarbonates, chloride, phosphate, nitrates, sulphates of calcium, magnesium, potassium and sodium are dissolved in water. The High concentration of TDS in drinking water may result as corrosion, incidence of cancer, coronary heart diseases, arteriosclerotic heart diseases and cardiovascular diseases. Bureau of Indian Standard prescribed the desirable limit $500 \mathrm{mg} / \mathrm{l}$ and permissible limit $2000 \mathrm{mg} / \mathrm{l}$ for total dissolved solid in water.

According to the Table-4, the district is affected by poor quality of drinking water, with 142 Habitations in Gangapur, 103 in Boni and 75 in Bamanwas. The blocks most affected by fluoride in water are Bonli, Gangapur, Bamanwas and Chauth Ka Barwada .Blocks affected by nitrate in ground water are Bonli, Gangapur and Chauth Ka Barwada. Blocks affected by TDS are Bonli, Bamanwas and Gangapur. It is clear from Table- 4 that the quantity of fluoride and iron is not found in the underground water of all the 6 blocks of Sawai Madhopur district.

Table 04: Water Quality Testing Block wise in Sawai Madhopur

\begin{tabular}{|c|c|c|c|c|c|c|c|c|c|c|}
\hline \multirow[t]{2}{*}{\begin{tabular}{|l|l|}
$\#$ & B \\
\end{tabular}} & \multirow[t]{2}{*}{ Block } & \multirow{2}{*}{$\begin{array}{c}\text { No. of } \\
\text { Sources } \\
(25 / 10 / 2019)\end{array}$} & \multirow{2}{*}{$\begin{array}{l}\text { No. of public } \\
\text { taps as on } \\
(25 / 10 / 2019)\end{array}$} & \multicolumn{6}{|c|}{$\begin{array}{l}\text { No. of Sources found contaminated } \\
\text { (above IS - } 10500 \text { Permissible limit) }\end{array}$} & \multirow{2}{*}{$\begin{array}{c}\text { No. of } \\
\text { Habs } \\
\text { Affected }\end{array}$} \\
\hline & & & & $\begin{array}{l}\text { Arsenic } \\
\text { (As) }\end{array}$ & $\begin{array}{c}\text { Fluoride } \\
\text { (FI) }\end{array}$ & $\begin{array}{l}\text { Nitrate } \\
\text { (NO3) }\end{array}$ & $\begin{array}{l}\text { Salinity } \\
\text { (TDS) }\end{array}$ & $\begin{array}{l}\text { Iron } \\
\text { (Fe) }\end{array}$ & $\begin{array}{l}\text { Bacterio- } \\
\text { logical }\end{array}$ & \\
\hline & $\begin{array}{l}\text { Chauth Ka } \\
\text { Barwada }\end{array}$ & 3179 & 39 & 0 & 101 & 140 & 58 & 0 & 0 & 56 \\
\hline 2 & Bamanwas & 4568 & 25 & 0 & 171 & 115 & 136 & 0 & 0 & 75 \\
\hline 3 & Gangapur & 3627 & 155 & 0 & 181 & 196 & 110 & 0 & 0 & 142 \\
\hline 4 & Bonli & 5192 & 90 & 0 & 252 & 216 & 147 & 0 & 0 & 103 \\
\hline 5 & \begin{tabular}{|l|} 
Sawai \\
Madhopur
\end{tabular} & 3182 & 118 & 0 & 13 & 81 & 6 & 0 & 0 & 40 \\
\hline 6 & Khandar & 2273 & 52 & 0 & 22 & 71 & 5 & 0 & 0 & 43 \\
\hline & Total & 22021 & 479 & 0 & 740 & 819 & 462 & 0 & 0 & 459 \\
\hline
\end{tabular}

Source: NRDWR

According to the study of some drinking water sources in the district (Table-4), it has been found that a total of 459 habitations have been affected due to poor water quality in the district, out of which 142 habitations is in Gangapur block and lowest 40 habitation is in Sawai Madhopur, 43 habitation Khandar block.

\section{Government Initiatives}

A water secure nation will not only provide clean and safe drinking water to its citizens but also would ensure a healthy and economically productive society. Supply of potable drinking water has been a top priority of Central and State Government. In the same context, various schemes are run by the Central and State Governments for providing clean drinking water in urban and rural areas in the state. The details of the major schemes providing drinking water facility to the state are as follows: According to the Niti Aayog CWMI (Composition Water Management Index) report (July, 2018), only 44 per cent of Rajasthan's rural areas have clean drinking water supply. The state has been applauded for its efforts in surface water restoration and participatory irrigation. Apart from this, Rajasthan has undergone improvement on the irrigation front by restoring 80 per cent of the irrigation potential largely through community managed ponds and tanks. The restoration of surface water bodies and other works done under Mukhyamantri Jal Swavlamban Abhiyan (MJSA) for the improved showing of the state. The state launched Mukhya Mantri Jal Swawlamban Yojana to short out the problems of water scarcity by restructuring the water bodies. After the execution of the Mukhya Mantri Jal Swavlambhan Abhiyan (MJSA) phase-I in the state, The Impact Assessment report shows an average rise of 4.66 feet in water table in 21 non-desert districts, 56.13 percent reduction in water supply through tankers and 63.64 percent rejuvenation of defunct hand-pumps and an increase of 44409 hectare of cropping area among other achievements.

Rajasthan government's Isarda Dam project, which would ensure supply of water to around 3.35 million people in Sawai Madhopur and Dausa districts. Dam will resolve drinking water problems of Dausa, Sawai Madhopur. The dam which will be built on 7,129 hectares of land in Isarda in Sawai Madhopur district and have a capacity of 10,770 million cubic feet of water. The Eastern Rajasthan Canal Project (ERCP) is to provide safe drinking water and irrigation water to targeted population of 13 districts of eastern Rajasthan and en-route towns, 
tanks and villages as well as nearby command area. The ERCP will ensure availability of water in Jhalawar, Baran, Kota, Bundi, Sawai Madhopur, Ajmer, Tonk, Jaipur, Dausa, Karauli, Alwar, Bharatpur and Dholpur districts and create an additional command area of 2 lakh hectares for irrigation.

The Government of Rajasthan through Public Health Engineering Department (PHED), Jaipur awarded the work of Chambal-Sawai Madhopur-Nadauti (CSN) Water Supply Project to provide drinking water facility to 926 villages and 4 towns, Sawai Madhopur, Gangapur, Karauli and Todabhim. These districts are adversely placed as far as availability of potable drinking water is concerned due to high nitrates, chlorides and dissolved solid contents and is not fit for human consumption.'Swajal' was originally launched as a pilot scheme in February 2018 in Six States including Rajasthan to provide sustainable access to drinking water to people in the rural areas. Later, it was extended to all the 112 aspirational districts identified by NITI Aayog. The Central Government has also come up with a World Bank-aided Atal Bhujal Yojana (ABHY) with community participation to ensure sustained groundwater management in overexploited and ground water-stressed areas in seven states. It has been found that 1034 blocks out of the 6584 assessed blocks in the country are overexploited including 164 blocks from Rajasthan. The Jal Shakti Abhiyan - a campaign for water conservation and water security in 1592 water stressed blocks in 256 districts, to ensure five important water conservation interventions. These will be water conservation and rainwater harvesting, renovation of traditional and other water bodies/tanks, reuse, bore well recharge structures, watershed development and intensive afforestation. The movement is a time-bound mission mode water conservation campaign. Jal Jeevan Mission, a central government initiative under the Ministry of Jal Shakti, aims to ensure access of piped water for every household in India. The mission's goal is to provide to all households in rural India safe and adequate water through individual household tap connections by 2024.

\section{Suggestions}

Water conservation is a key challenge, which requires public participation. Mass awareness on the need for water conservation and providing common tips to effectively participate in this important mission is need of the time. Rainwater, which is the purest form of water, has been collected and stored for later use for centuries. If collected properly, it would not only provide the supply of safe drinking water but also help in combating water borne diseases to a great extent. The following suggestions need to be adopted for providing clean drinking water facilities in urban and rural areas of Sawai Madhopur district.

- To enable the rural community shoulder the responsibility in management operation and maintenance of water supply systems at village level, decentralized, demand-driven, community managed approach in the form of Swajal Dhara have been adopted.

- There is need for more roles of Panchayati Raj Institutions (PRIs) in making the drinking water supply schemes functional. Partnership between village communities, NGOs, and The government as the facilitator and co-financing has worked successfully.

- Revival of traditional rainwater harvesting (TRH) structures i.e. kundi, kui/beri, baori/ber, jhalara, nadi, toba, tanka, khadin, johad and anicut etc. for rainwater conservation for use in day to day life will reduce ground water draft.

- Mass awareness programmes should be arranged at local level to make common people aware of importance of ground water resources, its better practices of use in domestic, irrigation and industrial sectors, present status of ground water scenario, need and ways of its conservation etc.

\section{Conclusion}

In terms of the critical issues for the drinking water such as source sustainability, water quality management and better operation and maintenance, it is important that strong grassroots awareness is generated. More participatory processes need to be adopted to involve all sections of the community for providing water services. Plans have been envisaged for the construction of artificial recharge and rainwater harvesting structure in rural areas. there is need to go for a rigorous convergence drive of Gol's various rural development programmes, such as Mahatma Gandhi National Rural Employment Guarantee Act, Pradhan Mantri Krishi Sinchayee Yojana, other scheme for watershed development and restoration of water bodies, etc., backed by a need based village-level water planning. An assured supply of safe and adequate drinking 
water can also be seen as one of the basic factors determining the quality of life of people and in the process enhancing their quality of life. Further, the field studies have revealed that a good number of villages in the country are maintaining $O \& M$ with the active participation of communities, especially women resulting in $27 \times 7$ safe drinking water supply on a sustainable manner. This is one of the contributing factors for preventing water borne diseases in achieving health for all. We have to increase water use efficiency in every sphere of life as well. This is even more so as the burgeoning population and people's consuming lifestyles have been putting tremendous strain on the limited natural resources of the country. Situation demands that the existing water resource be used very judiciously and prudently.

\section{References}

1. Alan C. Twort, D.M J Ratnnayaka and M.J. Brandt (2000) "Water Supply: 5th edition, Butterworth and Heinemann Publishers, Oxford.

2. BIS, (2012) Indian Standard IS: 10200: 2012- drinking Water Specification (Second Edition), Bureau of India Standards, New Delhi.

3. Brindha K. Vaman K.V.N., Srinivasan K. (2013) Identification of surface water ground water interaction by hydro geo chemical indicator and assessing its suitability for drinking purpose in Chennai, Southern, India. Springer 4, 159-174.

4. Central Ground Water Board, (2019) Government of India, Faridabad, Dynamic Ground Water Resources of India-2017.

5. CGWB (2013) Ground water brochure, Sawai Madhopur district, Rajasthan. Central Ground Water Board, Western Region, Jaipur, p.10.

6. Chaturvedi, M.C. (1987) "Water Resources Systems Planning and Management" Tata McGraw-Hill Publishing Company Limited, New Delhi.

7. Dezuane, John (1997) "A Handbook of Drinking Water Quality" 2nd Edition, John Wiley \& Sons. Inc.

8. Dhingra P, Singh Y (2014) Quality status of potable water of tehsil Amber district Jaipur Rajasthan India. Research Journal of chemical and environment science. Vol.2 (6) PP 43.

9. Gautam, H.R. (June 2019) Ensuring Safe and Adequate Drinking Water. Kurukshetra.

10. Ground Water Quality Status of Rajasthan (2013) Public Health Engineering Department, Jaipur, Rajasthan (India).

11. Kumari, S (May 2015) Drinking Water Quality in Rural India. Kurukshetra.

12. Li $\mathrm{Y}$ et al. (2001) Effect of long-term exposure to fluoride in drinking water on risks of bone fractures. Journal of Bone and Mineral Research, 16(5):932- 939.

13. Mandour R.A. (2012) Human health impacts of drinking water (surface and ground) pollution springer journal 2 P157-163.

14. Meena P.L., Jain P.K. and Meena K.S. (2016) Assessment of ground water quality and its suitability of drinking and domestic uses by WEI and statically analysis in river basin area in Jahajpur, Bhilwara, Rajasthan (India). International Journal Current micro app. Sci. 5 (3) PP 415-427.

15. Ministry of Water Resources, GOI: National Water Policy, 2012.

16. Ministry of Water Resources, GOR, Jaipur: State Water Policy, 2010.

17. Mukherjee, S., Z. Shah and M. D. Kumar (2010) "Sustaining Urban Water Supplies in India: Increasing Role of Large Reservoirs", Water Resources Management, Vol. 24, No. 10, pp. 2035-2055.

18. Saini P. and Khan T.I. (2014) Ground water fluoride content and water quality in Neem ka Thana Tehsil of Sikar district International Journal of Basic and Applied Chemical science Vol-4(1), PP-14-17.

19. Saurabh S., Singh D., Tiwari S. (2014) Drinking water quality of Rajasthan district. Journal of Basic and applied Engineering research. Vol. 1 PP 105- 109.

20. Sharda, V.K, Sikka, A.K., Samra, J.S. and Islam Adlul (2017) Water harvesting and recycling - Indian experiences. Publ: ICAR, New Delhi, pp. 1-337.

21. Singh, S. and Rathore, M. S., (2010) Rainfed Agriculture in India - Perspectives and Challenges, Rawat Publications, Jaipur.

22. Yadav A.K., Khan Praveen, Sharma S.K. (2010 Water quality index assessment of ground water in Todaraisingh tehsil of Rajasthan state, India A green approach Journal of Chemistry $7(\mathrm{~S} 1)$, s428-s432. 